\title{
DUST-INDUCED ALBEDO GHANGES OF POLAR ICE SHEETS AND GLACIERIZATION
}

\author{
By M. R. BLOGH \\ (The Negev Institute for Arid Zone Research, Beersheva, Israel)
}

\begin{abstract}
Amstract. The eustatic changes of the ocean in prehistoric and historical times are linked with the fate of the ocean-based salt industry, and are recognized as erratic. An hypothesis is proposed to explain these erratic changes with albedo changes of the polar ice sheets, caused in turn by erratic volcanic dust fall-out. Ash layers in Antarctic ice cores are connected with historical dislocations of maritime civilizations.

Albedo changes associated with the dusting of ice sheets are considered to be the cause of the decline of periods of glacierization generally. Such albedo changes are connected with volcanic activity on the one hand, and loess formation on the other, caused in turn by the growth of the ice sheets.
\end{abstract}

RÉsumé. Les variations eustatiques de l'océan au cours des époques préhistorique et historique sont liées au destin de l'industrie saline basée sur les eaux de mer, et sont connues comme étant aléatoires. On avance une hypothèse pour expliquer ces variations aléatoires au moyen des variations d'albedo des calottes polaires, causées elles-mêmes par des dépôts variables de poussières volcaniques. On relie les couches de cendres des carottes de glace de l'Antarctique aux dislocations historiques des civilisations maritimes.

Les variations d'albedo associées au dépôt de poussière sur les ice-sheets sont considérées comme étant à l'origine du déclin des périodes de glaciation en général. De telles variations d'albedo sont mises en regard de l'activité volcanique d'une part, et de la formation du loess d'autre part, et sont occasionnées elles-mêmes par l'accroissement des ice-sheets.

Zusammenfassung. Die eustatischen Schwankungen des Meeresspiegels in prähistorischer und historischer Zeit entschieden über die Möglichkeiten zur Gewinnung von Meeressalz; sie müssen als regellos betrachtet werden. Die vorliegende Hypothese versucht eine Erklärung dieser regellosen Schwankungen aus AlbedoSchwankungen der polaren Eiskappen, die ihrerseits durch regellosen Fall vulkanischen Staubes verursacht sind. Aschen-Lagen in Bohrkernen antarktischen Eises werden mit historisch bekannten Verlagerungen maritimer Kulturen verknüpft.

Albedo-Schwankungen, hervorgerufen durch Verschmutzung der Eiskappen, werden als die allgemeine Ursache für den Rückgang von Vergletscherungen betrachtet. Solche Albedo-Schwankungen sind einerseits mit vulkanischer Aktivität, andererseits mit Löss-Ablagerungen, verursacht durch das Anwachsen der Eiskappen, verknüpft.

IT is probable that dislocations of vital solar and peat salt production occurred in consequence of eustatic changes in sea-level throughout the ages; these sea-level changes caused the transfer of salt production from the coastal areas to inland salt sources and vice versa (Bloch, г962, г963).

Since these shifts indicate that sea-level changes were rather abrupt and erratic, it follows that the causes which brought them about, i.e. the melting and rebuilding of polar ice sheets (Daly, I920), were also abrupt and erratic. The possible reason for such sudden variations could be due to volcanic eruptions and dust formation on a world-wide scale (Bloch and Hester, 1963 ).

We have had extensive experience with influencing the effects of solar radiation on white areas by colouring them and thereby increasing the absorption of the visible part of the Sun's radiation. The output of a power station in the Andes was increased considerably by blackening (with a few tons of coal dust)* the glacier that feeds its water turbines; by colouring the brines in solar ponds with naphthol green, the evaporation was stepped up greatly and more white salts were produced (Bloch and Martin, I935; Bloch and others, I944, I95 r ; Bloch and Weiss, 1959). In both cases, the absorption of the visible part of the solar spectrum was increased.

Comparatively small quantities of colouring matter can notably influence the absorption characteristics of snow in the visible part of the spectrum, and since the visible part of the spectrum is almost $5^{\circ}$ per cent of the energy derived from the Sun on an ice or snow field, it

* I. Jakobson (in Grazhdanskaya Aviatsiya, Tom 4, No. 6, 1934, p. 264) states: "snow field treated, ablation $40 \mathrm{~cm}$. from 18 March to 12 April; snow field untreated, io cm. from 18 March to ig April". (Only the translation of this was available to the author.) 
follows that the discolouration of white areas can significantly increase the energy uptake of glaciers and snow fields. It seems reasonable to assume that an outbreak of volcanic eruption such as that of Krakatao in the I88o's could have discoloured areas like the polar ice sheets with dust over a period of several years, through continuous fall-out. Such greyness is difficult to discern visually and, even when strong, it can only be determined by physical measurements and chemical analysis.

Albedo changes of the polar ice sheets might have very different consequences under different circumstances (Spethmann, I908; Hannell and Ashwell, 1959, p. 87; Stuart and Bull, I963, p. 413).

If through increased energy absorption more ice melts because the ice or snow is near melting point, then the quantity of water in the ocean will increase, but only slight changes in climatic features will be caused. However, a change in the level of the ocean in this case can only be expected if ice on a land base has been melted. When melted, floating ice will not cause any level changes, but ice on solid ground will, if it is forced to travel faster into the ocean.

Whenever ice or snow absorbs more energy through discolouration and whenever it can warm up without melting, then considerable world-wide changes in climatic features like humidity, temperature, and intensity and direction of air streams can be expected. This may be the case with very large and very cold Antarctic ice masses affected by only slight albedo changes, resulting in symptoms such as the steep rise of the inland lakes (the Dead Sea after ı 883) (Klein, I96i).

It would be interesting to compare the stratification of glaciers such as those on Axel Heiberg Island with the known outbreaks of volcanicity in the Northern Hemisphere and the corresponding changes in climate and sea-level recorded.

Similarly it might be possible to correlate the ash layers of $172 \cdot 1,219 \cdot 4$ and $222.8 \mathrm{~m}$. found in the "Little America" cores by Crary and others (I962), and dated 1920, 3150 and $333^{\circ}$ B.P., respectively, to eustatic rises of about A.D. IOO and I 200 B.C.; for the first date (the first half of the first millennium A.D.) a period of high sea-level is almost certain. It caused the flooding of Mediterranean ports, the East Anglian fens, the Dutch island of Zeeland and many saltairns on the Mediterranean coast.

This in turn probably caused considerable ethnic dislocations at the end of the western Roman Empire, and the high activity of the Nabatean and Lybian desert salt trade at the same time. It also seems quite reasonable to associate the two ash layers of I 200 B.c. with the well-known breakdown of the maritime Mycenaean civilization and the contemporary high activity of continental civilizations near desert salt sources like the Dead Sea (culmination of the Judean hill kingdoms).

The working hypothesis of connecting the albedo of the polar ice sheets with eustatic sea-level changes in historic times leads to an hypothesis for the explanation of major glacial periods.

It is known that the end of each of these periods coincided with increased volcanic eruptions (Sarasin and Sarasin, I902; Salmi, r94I) on the one hand and aridity on the other (loess formation). (This coincidence was previously dealt with in connection with the increased $\mathrm{CO}_{2}$ content and dust clouds in the atmosphere as being a possible cause of consequent climatic changes.)

Lister (1959, p. I67) has calculated that the Antarctic gains on average I $3 \cdot$ I g. $/ \mathrm{cm} .{ }^{2} \mathrm{yr}$. of ice, and loses $\mathrm{IO} \cdot \mathrm{I} \mathrm{g} . / \mathrm{cm} .{ }^{2} \mathrm{yr}$., yielding a net increase of $3 \mathrm{~g} . / \mathrm{cm} .{ }^{2} \mathrm{yr}$. Taking this at face value, the growth of the Antarctic Ice Sheet under present "normal" conditions can be anticipated. The thickness of the ice should increase by about $\mathrm{I} \mathrm{km}$. in $30,000 \mathrm{yr}$., and an increase in diameter of the ice sheet would be connected with this. 
The crust of the Earth, having to carry an additional local weight of $\mathrm{I} \mathrm{km}$. of ice, would then become increasingly unstable, and the release of stresses thus built up would give rise to tectonic movements and volcanic outbreaks in the areas of already preformed instability (in agreement with Salmi (I94I)).

The volcanoes near the ice sheets have, at the end of glacial periods, thrown many cubic kilometres of ash into the air, and appreciable thicknesses of this ash formed covering layers on areas quite commensurable with the size of the Arctic and Antarctic Ice Sheets (Smith, I960). Furthermore, increased size of the ice sheets in the Arctic and Antarctic seem to have caused arid conditions in the adjoining regions. Loess formation and dust storms were characteristic at the time of maximum ice sheet extension.

From direct investigations and experience on glaciers, it is known that ash and dust layers will greatly increase the ablation of ice; since the temperature of snow cores has been found to reach a maximum in a depth of several centimetres, ash or dust covered by many centimetres of new snow or admixed more or less homogeneously with the snow would still increase absorption of visible light.

In the Antarctic, absorption of visible light through discolouration of snow might increase the energy absorbed by $35 \mathrm{cal} . / \mathrm{cm} .{ }^{2} \mathrm{yr}$. This, in turn, would cause the warming up of the ice sheet, melting and increased evaporation. It seems an important field for experimentation to investigate how this additional energy is distributed in depth under different conditions.

Albedo changes of dusted polar ice sheets could affect the overall energy balance of the Earth by the order of I per cent. If this energy is expended mostly for melting the ice, the world's oceans could rise by more than I cm./yr. The thickness of the ice sheets would diminish by several metres per year. In this way tectonic stability could return after a comparatively short time, say after a few thousand years. A similar mechanism can be assumed for the North Pole; only there, the influence on ocean level would cease when the ice sheet eventually leaves the continent and retreats to the polar ocean. This was practically the case at the end of the last glaciation and, in consequence of this, the eustatic post-glacial ocean level rise was steep only until 8000 B.P.; after this time changes became small and erratic, probably due to albedo variations which occurred mainly in the Antarctic.

If this hypothesis is correct, then there is no apparent reason why the ash- or dustconditioned glacial periods at the North and South Poles should coincide - other than accidentally.

It would therefore be quite possible for a period of high temperature, melting and retreating ice in the Antarctic to coincide with increasing glacierization in the North Pole regions.

However, if by chance severe glacierization at both poles coincided, then an extraordinarily low ocean level would occur. Vice versa, if by chance peak volcanic activity and dust storms coincide at the North and South Pole regions, then an extraordinarily high level of the world's oceans can be expected.

MS. received 23 Fuly 1963

\section{REFERENCES}

Bloch, M. R. 1962. Melah adom umelaḥ afor: 'aliyyātān vīrīdātān shel mamlākhot k'toșā'ā me'aliyyā vĩrīdā shel pne hayyammim hamme'afsherōt ō mōn'ōt tahalikhe hafākat melaḥ [Red and grey salt: the rise and decline of kingdoms as a result of the rise and decline of sea levels which enable or prevent the processes of salt production]. Mada [Science] (Jerusalem), Vol. 6, No. 4, p. 3-8.

Bloch, M. R. I963. The social influence of salt. Scientific American, Vol. 209, No. 1, p. 89-96, 98.

Bloch, M. R., and Hester, W. B. 1963 . Climate and volcanic outbreaks. Bulletin. Research Council of Israel, Sec. G, Vol. i IG, No. 4, p. I 73-74.

Bloch, M. R., and Martin, H. I935. Verfahren zur Gewinnung von Salzen aus salzhaltigen Laugen durch Verdampfen mittels Sonnen-Energie. Deutsches Reichs Patent Nr. 66049o. 
Bloch, M. R., and Weiss, T. I959. Evaporation rate of water from open surfaces coloured white. Bulletin. Research Council of Israel, Sec. A, Chemistry, Vol. 8A, No. 4, p. I88-89.

Bloch, M. R., and others. 1944. Occasional whiteness of the Dead Sea, by M. R. Bloch, H. Z. Littman and B. E. Volcani. Nature, Vol. I 54, No. 3908, p. 402-03.

Bloch, M. R., and others. 1951. Solar evaporation of salt brines, by M. R. Bloch, L. Farkas and K. S. Spiegler. Industrial and Engineering Chemistry, Vol. 43, No. 7, p. 1544-53.

Crary, A. P., and others. 1962. Glaciological regime of the Ross Ice Shelf, by A. P. Crary, E. S. Robinson, H. F. Bennett and W. W. Boyd, Jr. Journal of Geophysical Research, Vol. 67, No. 7, p. $2791-807$.

Daly, R. A. 1920. A recent worldwide sinking of ocean-level. Geological Magazine, Vol. 57, No. 6, p. 246-61.

Hannell, F. G., and Ashwell, I. Y. 1959. The recession of an Icelandic glacier. Geographical Journal, Vol. I 25, Pt. I, p. $84-88$.

Klein, C. 196r. On the fluctuations of the level of the Dead Sea since the beginning of the r 9 th century. Israel. Ministry of Agriculture. Water Commission. Hydrological Service Paper No. 7.

Lister, H. 1959. The characteristics of the Antarctic Ice Sheet. Geophysical Fournal, Vol. 2, No. 2, p. I64-68. [Discussion.]

Salmi, M. 1941. Die postglazialen Eruptionsschichten Patagoniens und Feuerlands. Annales Academiae Scientiarum Fennicae, Ser. A, III. Geol.-Geogr., No. 2, p. I-I 15 .

Sarasin, P., and Sarasin, F. 1902. Über die mutmassliche Ursache der Eiszeit. Verhandlungen der Naturforschenden Gesellschaft in Basel, Bd. 13, Ht. 3, p. 603-18.

Smith, R. L. 1960. Ash flows. Bulletin of the Geological Society of America, Vol. 71, No. 6, p. 795-841.

Spethmann, H. 1908. Schneeschmelz Kegel auf Island. Zeitschrift für Gletscherkunde, Bd. 12, Ht. 4, p. 296 -301.

Stuart, A. W., and Bull, C. I963. Glaciological observations on the Ross Ice Shelf near Scott Base, Antarctica. Fournal of Glaciology, Vol. 4, No. 34, p. 399-414. 